GRASAS Y ACEITES 66 (2)

April-June 2015, e075

ISSN-L: 0017-3495

doi: http://dx.doi.org/10.3989/gya.0833142

\title{
Habitat induced mutational effects and fatty acid profile changes in bottom dweller Cirrhinus mrigala inhabitant of river Chenab
}

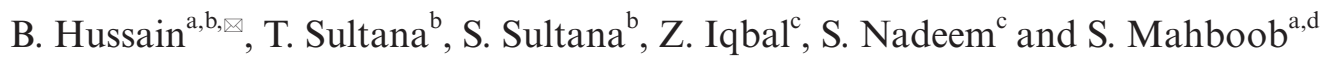 \\ ${ }^{a}$ Department of Zoology, Wildlife and Fisheries, Govt. College University, Faisalabad, Pakistan \\ ${ }^{b}$ Department of Bioinformatics and Biotechnology, Govt. College University, Faisalabad, Pakistan \\ ${ }^{c}$ Nuclear Institute for Agriculture and Biology, Faisalabad, Pakistan \\ ${ }^{\mathrm{d}}$ Department of Zoology, College of Science, King Saud University, P.O. Box 2455, Riyadh, Saudi Arabia \\ ${ }^{\square}$ Corresponding author: profbilal@yahoo.com
}

Submitted: 25 August 2014; Accepted: 23 December 2014

\begin{abstract}
SUMMARY: Fish from the river Chenab were analyzed for DNA damage by the Comet and Micronucleus assays. The fatty acid profile was determined by gas chromatography using a Flame Ionization Detector. Atomic absorption spectrophotometry showed significant $(p<0.05)$ levels of contamination due to $\mathrm{Cd}, \mathrm{Hg}, \mathrm{Cu}, \mathrm{Mn}$, $\mathrm{Zn}, \mathrm{Pb}, \mathrm{Cr}, \mathrm{Sn}$ and phenols in the fish habitat. The Comet assay revealed significant $(p<0.05)$ DNA damage in Cirrhinus mrigala of $37.29 \pm 2.51 \%, 34.96 \pm 2.53 \%$ and $38.80 \pm 2.42 \%$ in the comet tail, in the tail moment of $23.48 \pm 3.90,19.78 \pm 4.26$ and $14.30 \pm 1.82$, in the olive moment of $16.22 \pm 2.04,13.83 \pm 1.9610 .99 \pm 0.90$, respectively, from three experimental sites. The micronucleus assay showed a high frequency of single micronucleus induction of $44.80 \pm 3.73$, double induction of $06.20 \pm 0.97$ and nuclear abnormalities of $09.60 \pm 1.72$, as calculated in a thousand cells. C8:0, C12:0, C20:0, C16:1(n-7), C16:1(n-9), C20:1(n-9), C18:2(n-6), C18:4(n-3), $\mathrm{C} 20: 5(\mathrm{n}-3), \mathrm{C} 22: 4(\mathrm{n}-6)$ fatty acids were found missing in the fish with a higher intensity of DNA damage but were found in optimal amounts both in farmed and wild fish from non polluted habitats. A highly significant $(p<0.01)$ correlation was also found in saturated, unsaturated fatty acids and DNA damage and habitat. The present study revealed that the habitat of even lower intensity pollutions not only induce DNA damage but also confiscate essential fatty acids of the omega series and reduce the amount of unsaturated fatty acids for which fish is preferred over other animals.
\end{abstract}

KEYWORDS: Cirrhinus; DNA damage; Fatty acids; Habitat; Niche; Pollution

RESUMEN: Efectos inducidos por el hábitat sobre mutaciones y perfil de ácidos grasos en carpas mrigala que habitan en el fondo del río Chenab. Los daños en el ADN de los peces del río Chenab se analizaron mediante la técnica del "ensayo del cometa" y el ensayo de micronúcleos. El perfil de ácidos grasos se determinó mediante cromatografía de gases con detector de ionización de llama. La espectrofotometría de absorción atómica mostró diferencias significativas $(p<0.05)$ de los niveles de contaminación por $\mathrm{Cd}, \mathrm{Hg}, \mathrm{Cu}, \mathrm{Mn}, \mathrm{Zn}, \mathrm{Pb}, \mathrm{Cr}, \mathrm{Sn}$ y fenoles en el hábitat de los peces. El ensayo del cometa mostró daños significativos $(p<0,05)$ en el $\mathrm{ADN}$ de las carpas mrigala de tres sitios experimentales: $37,29 \pm 2,51 \%, 34,96 \pm 2,53$ y $38,80 \pm 2,42 \%$ del ADN en la cola del cometa, momento de la cola con $23,48 \pm 3,90,19,78 \pm 4,26$ y $14,30 \pm 1,82 \%$ y cola media con $16,22 \pm 2,04$, $13,83 \pm 1,9610,99 \pm 0,90$. Los ensayos de micronúcleos mostraron una alta frecuencia de inducción de micronúcleos como única 44,80 $\pm 3,73,06,20 \pm 0,97$ y doble anomalías nucleares $09,60 \pm 1,72$ calculados en miles de células. C8:0, C12:0, C20:0, C16:1(n-7), C16:1 (n-9), C20:1(n-9), C18:2(n-6), C18:4(n-3), C20:5(n-3) у C22:4(n-6) se mostraron como ácidos grasos que faltan en el pescado que tiene una mayor intensidad de daño en el ADN, aunque se encuentran en cantidades óptimas, tanto en los peces de piscifactoría como en los salvajes donde no hay hábitats contaminados. Se encontró una correlación altamente significativa $(p<0,01)$ también en ácidos 


\begin{abstract}
saturados, ácidos grasos insaturados, daño del ADN y hábitat. El presente estudio reveló que la intensidad de la contaminación del hábitat aún en la más baja no sólo induce daño en el ADN, sino también en la composición de los ácidos grasos de la serie omega y de los ácidos grasos insaturados, para los que se prefiere ingerir pescado a otros animales.
\end{abstract}

PALABRAS CLAVE: Ácidos grasos; Carpas; Contaminación; Daño en el ADN; Hábitat; Nicho

Citation/Cómo citar este artículo: Hussain B, Sultana T, Sultana S, Iqbal Z, Nadeem S, Mahboob S. 2015. Habitat induced mutational effects and fatty acid profile changes in bottom dweller Cirrhinus mrigala inhabitant of river Chenab. Grasas Aceites 66 (2): e075. doi: http://dx.doi.org/10.3989/gya.0833142.

Copyright: (C) 2015 CSIC. This is an open-access article distributed under the terms of the Creative Commons Attribution-Non Commercial (by-nc) Spain 3.0 Licence.

\section{INTRODUCTION}

Fish farming is believed to be one of the most promising resources for animal protein. The potential and prolific nature of fish farming has been directed towards its large scale adoption and promotion in Asian countries. Coronary heart diseases have been identified as a leading cause of death in various parts of the world including Pakistan, with mortality rates increasing yearly. In recent years, fish lipids have also assumed a great nutritional significance owing to their protective role against the development of cardiovascular diseases and rheumatoid arthritis (Ackman, 1967; Burr et al., 1989; Polvi and Ackman, 1992; Shahidi and Boota, 1994). Fish lipids are rich in polyunsaturated fatty acids (PUFA) that are essential for fish growth and health. Fish store these lipids in muscles and in the liver, while on the contrary, in the majority of mammals, they are stored in their adipose tissues (Kiessling et al., 2001; Kandemir et al., 2007).

Changes in genome caused by genotoxic agents can lead to mutations. There is need to develop molecular bioassays which can remedy the detrimental effects of environment on living organisms. DNA damaging agents require continuous monitoring and detection (Villela et al., 2006). With increasing demand, the population of fish in different areas of the world has been reduced drastically due to pollution and overfishing (Baršienè et al., 2013; Pavlica et al., 2011). Polluted water from the industrial and urban areas of Faisalabad is being disposed into the River Chenab, which has led to the extinction and decrease in population of different fish species along a $190 \mathrm{Km}$ stretch of the River Chenab. The present research project was planned to evaluate the effect of pollution on the DNA damage and fatty acid profile of the fish in order to confirm the fact that fish not only bioaccumulate toxins in their bodies but that these toxins produce a reduced quality in the meat. There is a pressing need to reduce environmental pollution so that future generations may enjoy quality fish meat with a high quality lipid profile.

\section{MATERIALS AND METHODS}

\subsection{Procurement of Fish}

Cirrhinus mrigala (1000-1250 g) was collected from the River Chenab along its $190 \mathrm{~km}$ stretch spanning the District Jhang from Thatta Muhammad Shahh to Trimu Head from site S1, S2 and S3. This constitutes an area of immense pollution because of domestic sewage and industrial effluents that are being dumped into the River Chenab through the Chakbandi Drain (latitude $31.570^{\circ}$, longitude $\left.72.534^{\circ}\right)$. Control fish specimens were harvested upstream of a polluted area at Thalli, a comparatively non-polluted area. To make the results more elucidatory, fish from this area were compared to farmed fish species which inhabit a pollution-free environment.

\subsection{Preparation of fish for experiment}

All the fish specimens were cleaned by running under de-chlorinated tap water to facilitate the emptying and removal of stomach contents. Fish were then slaughtered and visceral organs were removed, followed by meat filleting. Fish muscle samples were stored at $-70{ }^{\circ} \mathrm{C}$, whereas fresh fish samples were preferred for fatty acid analyses. Fish sampling was performed from each experimental site in the winter and summer seasons for two consecutive years. Seven fish specimen from each site were collected and fresh muscle samples from each fish were oven dried and ground to powdered form.

\subsection{Water analysis}

Water samples were collected from each sampling site and analyzed for selected heavy metals and other water quality parameters. The concentration of each metal ( $\mathrm{Sb}, \mathrm{Cr}, \mathrm{Pb}, \mathrm{Zn}, \mathrm{Mn}, \mathrm{Cu}, \mathrm{Cd}$ and $\mathrm{Hg}$ ) was detected using heavy metal kits according to APHA (1998) with the Hitachi polarized Zeeman Atomic Absorption Spectrophotometer AAS, 2000 series. The water samples were analyzed in the analytical laboratory of the Environmental Protection 
Department, Faisalabad and the Biochemistry Laboratory Department of Zoology, at GC University, Faisalabad (Boyd, 1981).

\subsection{Fatty acid profiling}

Lipid contents were extracted from the powdered meat samples using a Soxhlet Extraction apparatus with n-Hexane heated to $65^{\circ} \mathrm{C}$ and further subjected to fatty acid analysis for meat quality according to the procedure of Folch et al. (1957), as modified by Bell et al. (1991). Extracted lipids were converted to fatty acid (FA) methyl esters using methanolic sulfuric acid through an esterification process and the samples treated with ether were injected into the Gas Chromatograph. The chromatograms produced from each sample were used to determine the retention time of each fatty acid (Fatty acid methyl esters (FAMEs)) and these were compared to the chromatogram of a standard (mixture of pure FAMEs). Fatty acids were determined by gas-liquid chromatography using a Flame Ionization detector (Kiessling et al., 2001).

\subsection{DNA damage}

The Comet assay or single cell gel electrophoresis (SCGE) is a convenient and sensitive method for detecting DNA breakage in an individual cell (Singh et al., 1988). The advantages of the SCGE technique include the collection of data at the individual cell level and require a small number of cells $(<10,000)$ per sample (Dhawan et al., 2009). Single-cell suspensions were prepared and then embedded into a low melting point agarose on frosted microscope slides. These Slides were placed in a lysing buffer to facilitate the unwinding of DNA. It was subsequently followed by electrophoresis and neutralization. The visualization of cells and the DNA was accomplished after staining with ethidium bromide.

Fresh blood was taken from the caudal vein of the fish and stored in heparin coated tubes at $4{ }^{\circ} \mathrm{C}$ for up to four days. In the micronucleus assay fresh blood was smeared on the slides, air dried and then fixed in a cold Corney's fixative for 5 minutes. After fixing, the slides were stained in an aqueous solution of $10 \%$ Giemsa for 30 minutes. The frequencies of micronuclei in erythrocytes were detected under a Binocular microscope at T1200x magnification. The erythrocytes with intact cellular and nuclear membranes were counted (Alink et al., 2007; Obiakor et al., 2010).

\subsection{Statistical analysis}

Mean, standard error and analyses of variance (ANOVA) were worked out through SPSS 9 for PC. The means were compared by using Duncan's
Multiple Range test. Analysis of Variance and Duncan's Multiple Range tests were performed to analyze differences between the parameters under study. Probability values of $p<0.05$ were considered significant. A DNA damage image analysis was performed with TriTek Comet Score ${ }^{\mathrm{TM}}$ Freeware 1.6.1.13 software Tritek Corporation, 2010.

\section{RESULTS}

The water quality parameter analysis showed acute levels of pollution load in the River Chenab (Figure 1). Heavy metals were present in the river water because of industrial and urban untreated waste water discharge in addition to natural sources. All heavy metals under study were found in significantly higher concentrations than WHO permissible limits. In the case of \% DNA in the tail, for site S1, a significant $(p<0.05)$ difference was observed between farmed and polluted area fish. Moreover, a significant difference was found for polluted and upstream area fish, whereas, a non-significant $(p>0.05)$ difference was observed between farmed and upstream area fish. For site S2, significant differences in $\%$ DNA in the tail were observed in polluted and upstream area fish specimens, although they were non-significant between farmed and upstream area fish specimens. For site S3, significant differences in $\%$ DNA in the tail were found in farmed, polluted and upstream area fish specimens. The maximum DNA damage was found in the fish collected from site S3 followed by sites S1 and S2, In the case of tail moment, significant differences were reported for polluted and upstream area fish specimens while in the case of site $\mathbf{S} 2$, non-significant $(p>0.05)$ differences were reported in all types including, +ve control, farmed, polluted and upstream area fish specimens. In the case of site S3, the tail moment showed significant differences for farmed and polluted area fish while non-significant differences were found between polluted and upstream area fish specimens (Figure 2). In the case of the olive moment, for site S1, significant $(p<0.05)$ differences were reported for farmed (Figure 3 ) and polluted as well as for polluted and upstream area fish specimens. Fish from site S2 showed significant differences in the olive moment for farmed and polluted area fish while non-significant differences were reported between farmed and upstream area fish. The olive moment for site $\mathrm{S} 3$ showed significant differences for farmed and polluted area fish (Table 1).

The fish collected from the polluted area of the River Chenab showed the highest frequency of micronucleus induction and even nuclear abnormalities (Figures 4 and 5). Cirrhinus mrigala showed a considerable amount of micronucleus induction even from the area of lower pollution intensity (upstream to the entrance of the Chakbandi drain) 


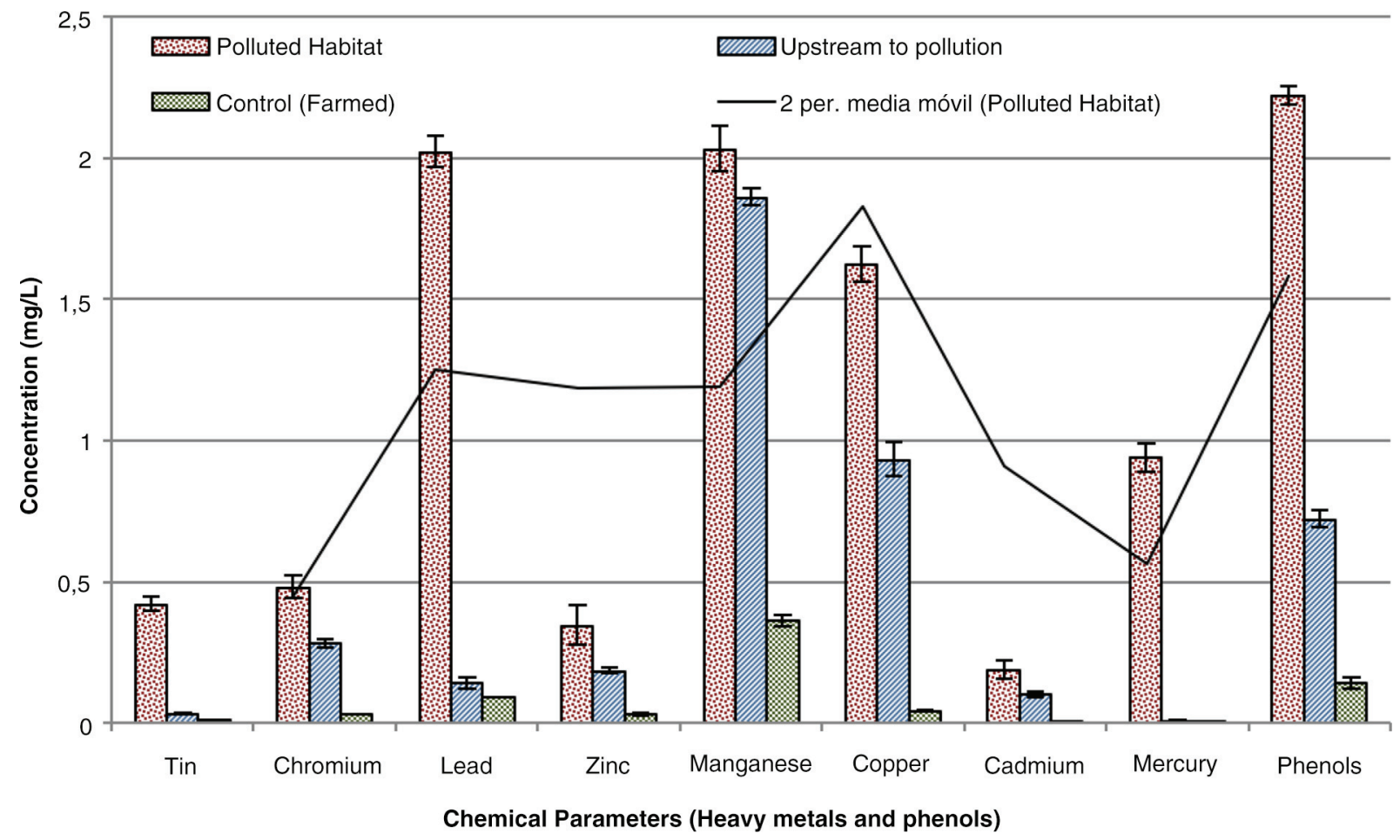

Figure 1. Comparative analyses of means for selected heavy metals and phenols from three different environments.

(Table 2). Perhaps this is due to the fact that the Cirrhinus mrigala is a bottom feeder and has maximum exposure to polluted sediments. The farmed (Control) fish showed negligible amounts of such types of DNA damage.

The observed changes in individual fatty acids of the total lipid fraction are depicted in Table 3. The data shown for individual fatty acid of total lipids are limited to the fish flesh of three different habitats. One from highly polluted areas where industrial and domestic wastes are dumped into the River Chenab through the chakbandi drain, and from the comparatively less polluted areas upstream of the River Chenab before the disposal of this drain into the river. These two categories were compared with

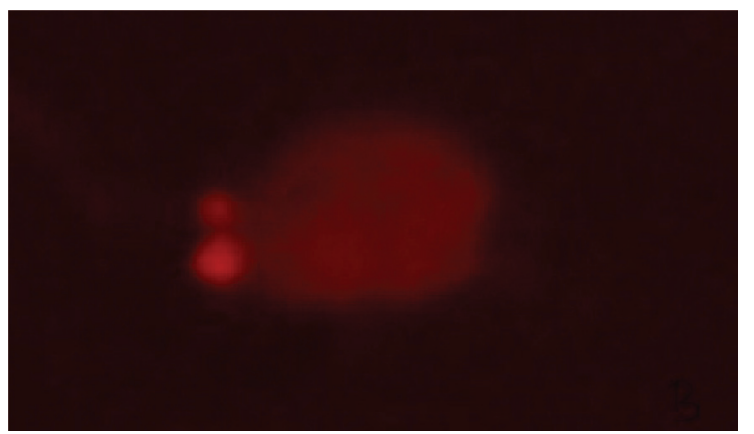

FiguRE 2. DNA fragmentation by Comet assay of the farmed fish (Cirrhinus mrigala), enlarged to illustrate (+ve control). farmed fish. A comparison of the aforementioned categories presented a clear "domino effect" and that this environment has developed into a highly toxic habitat which is not suitable for the growth of fish for producing high quality meat.

Fish from the highly polluted area showed a lower number of fatty acids and more saturated fatty acids in their meat as compared to that of the fish from less polluted areas. C8:0, C12:0, C16:1(n-7), C16:1(n-9), C20:1(n-9), C18:2(n-6), C18:4(n-3), $\mathrm{C} 22: 4(\mathrm{n}-6)$ fatty acids were missing in fish from the highly polluted habitat, where significant DNA damage was observed. Only eight fatty acids of the

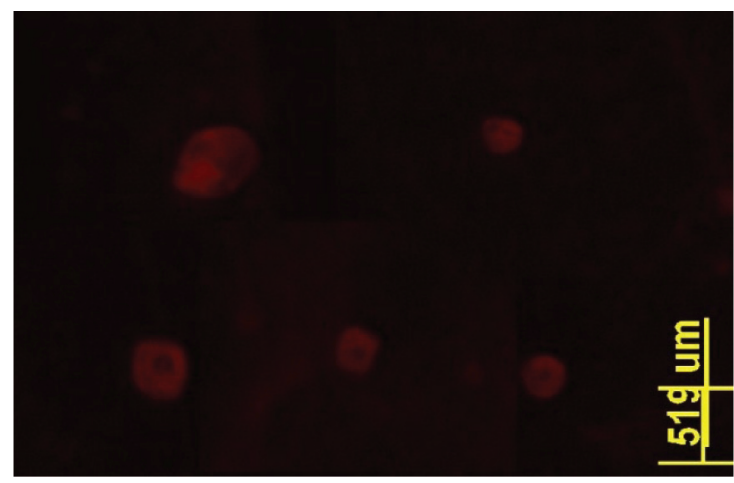

FIgURE 3. DNA fragmentation by Comet assay of the fish (Cirrhinus mrigala) harvested from farmed non-polluted environment. 
TABLE 1. DNA damage by Comet assay for Species, site and type interaction

\begin{tabular}{|c|c|c|c|c|c|}
\hline \multirow[b]{3}{*}{ Sites } & \multicolumn{5}{|c|}{ Species and site interaction (mean $\pm \mathrm{SE}$ ) } \\
\hline & \multicolumn{5}{|c|}{ Comet Assay Components } \\
\hline & Head Diameter (px) & Tail Length (px) & DNA in Tail (\%) & Tail Moment & Olive moment \\
\hline Site S1 & $89.79 \pm 4.16^{\mathrm{b}}$ & $31.37 \pm 2.87$ & $21.19 \pm 1.45$ & $12.16 \pm 1.53$ & $08.83 \pm 0.88$ \\
\hline Site S2 & $77.18 \pm 3.59^{\mathrm{c}}$ & $22.30 \pm 2.57$ & $16.40 \pm 1.31$ & $07.65 \pm 1.33$ & $06.09 \pm 0.71$ \\
\hline Site S3 & $90.92 \pm 3.07^{\mathrm{b}}$ & $30.96 \pm 2.53$ & $21.75 \pm 1.51$ & $10.45 \pm 1.10$ & $08.52 \pm 0.68$ \\
\hline Mean & $85.96 \pm 2.11^{\mathrm{B}}$ & $28.21 \pm 1.54^{\mathrm{A}}$ & $19.78 \pm 0.83^{\mathrm{A}}$ & $10.08 \pm 0.77^{\mathrm{A}}$ & $07.82 \pm 0.44^{\mathrm{A}}$ \\
\hline \multicolumn{6}{|c|}{ Species and type interaction (mean $\pm \mathrm{SE}$ ) } \\
\hline $\mathrm{Control}^{+\mathrm{ve}}$ & $108.82 \pm 5.74^{\mathrm{b}}$ & $35.43 \pm 3.54^{\mathrm{ab}}$ & $17.66 \pm 1.53^{\mathrm{bcd}}$ & $09.72 \pm 1.46^{\mathrm{bc}}$ & $07.92 \pm 0.87^{\mathrm{bc}}$ \\
\hline Farmed & $52.31 \pm 1.07^{\mathrm{h}}$ & $02.20 \pm 0.38 \mathrm{e}$ & $05.45 \pm 0.93 \mathrm{e}$ & $00.57 \pm 0.20^{\mathrm{d}}$ & $01.22 \pm 0.31^{\mathrm{d}}$ \\
\hline Polluted & $88.33 \pm 3.08^{\mathrm{cd}}$ & $41.41 \pm 3.14^{\mathrm{a}}$ & $37.01 \pm 1.43^{\mathrm{a}}$ & $19.19 \pm 2.03^{\mathrm{a}}$ & $13.68 \pm 1.00^{\mathrm{a}}$ \\
\hline Upstream & $94.37 \pm 4.05^{\mathrm{cd}}$ & $33.79 \pm 3.06^{\mathrm{ab}}$ & $19.00 \pm 1.52^{\mathrm{bc}}$ & $10.86 \pm 1.45^{\mathrm{b}}$ & $08.44 \pm 0.87^{\mathrm{b}}$ \\
\hline \multicolumn{6}{|c|}{ Species, site and type interaction (mean \pm SE) } \\
\hline $\mathrm{S} 1 \cdot+\mathrm{ve}$ & $147.32 \pm 10.7^{\mathrm{ab}}$ & $64.80 \pm 6.24^{\mathrm{a}}$ & $30.47 \pm 2.85^{\mathrm{abc}}$ & $23.12 \pm 3.52^{\mathrm{a}}$ & $16.40 \pm 1.95^{\mathrm{a}}$ \\
\hline $\mathrm{S} 1 \cdot \mathrm{F}$ & $51.86 \pm 1.65^{\mathrm{lmn}}$ & $01.32 \pm 0.34^{\mathrm{n}}$ & $03.81 \pm 0.64^{\mathrm{j}}$ & $00.12 \pm 0.04^{\mathrm{h}}$ & $00.65 \pm 0.13^{\mathrm{h}}$ \\
\hline $\mathrm{S} 1 \cdot \mathrm{P}$ & $104.02 \pm 4.66^{\text {def }}$ & $50.34 \pm 5.71^{\mathrm{abc}}$ & $37.29 \pm 2.51^{\mathrm{a}}$ & $23.48 \pm 3.90^{\mathrm{a}}$ & $16.22 \pm 2.04^{\mathrm{a}}$ \\
\hline $\mathrm{S} 1 \cdot \mathrm{U}$ & $55.94 \pm 4.35^{\mathrm{lmn}}$ & $09.02 \pm 1.75^{\mathrm{j}-\mathrm{n}}$ & $13.20 \pm 2.18^{\mathrm{d}-\mathrm{j}}$ & $01.92 \pm 0.39^{\mathrm{h}}$ & $02.06 \pm 0.38^{\mathrm{fgh}}$ \\
\hline $\mathrm{S} 2 \cdot+\mathrm{ve}$ & $37.42 \pm 2.84^{\mathrm{n}}$ & $06.36 \pm 1.23^{\mathrm{k}-\mathrm{n}}$ & $15.58 \pm 2.55^{\mathrm{d}-\mathrm{j}}$ & $01.97 \pm 0.59^{\mathrm{h}}$ & $02.63 \pm 0.44^{\mathrm{e}-\mathrm{h}}$ \\
\hline $\mathrm{S} 2 \cdot \mathrm{F}$ & $52.76 \pm 2.06^{\mathrm{lmn}}$ & $01.62 \pm 0.44^{\mathrm{n}}$ & $04.35 \pm 1.08^{\mathrm{ij}}$ & $00.28 \pm 0.10^{\mathrm{h}}$ & $00.79 \pm 0.19^{\mathrm{gh}}$ \\
\hline $\mathrm{S} 2 \cdot \mathrm{P}$ & $89.44 \pm 6.53^{\mathrm{f}-\mathrm{j}}$ & $43.42 \pm 6.61^{\mathrm{bee}}$ & $34.96 \pm 2.53^{\mathrm{a}}$ & $19.78 \pm 4.26^{\mathrm{ah}}$ & $13.83 \pm 1.96^{\mathrm{ab}}$ \\
\hline $\mathrm{S} 2 \cdot \mathrm{U}$ & $129.10 \pm 7.22^{\mathrm{bcd}}$ & $37.78 \pm 5.83^{\mathrm{b}-\mathrm{g}}$ & $10.73 \pm 1.80^{\mathrm{d}-\mathrm{j}}$ & $08.55 \pm 2.34^{\mathrm{c}-\mathrm{h}}$ & $07.12 \pm 1.42^{\mathrm{c}-\mathrm{g}}$ \\
\hline $\mathrm{S} 3 \cdot+\mathrm{ve}$ & $141.72 \pm 4.76^{\mathrm{abc}}$ & $35.12 \pm 6.27^{\mathrm{b}-\mathrm{h}}$ & $06.93 \pm 0.99^{\mathrm{f}-\mathrm{j}}$ & $04.06 \pm 1.06^{\mathrm{e}-\mathrm{h}}$ & $04.72 \pm 0.87^{\mathrm{d}-\mathrm{h}}$ \\
\hline $\mathrm{S} 3 \cdot \mathrm{F}$ & $52.32 \pm 1.87^{\mathrm{lmn}}$ & $03.66 \pm 0.98^{\mathrm{lmn}}$ & $08.19 \pm 2.48^{e-j}$ & $01.31 \pm 0.57^{\mathrm{h}}$ & $02.23 \pm 0.88^{\mathrm{fgh}}$ \\
\hline $\mathrm{S} 3 \cdot \mathrm{P}$ & $71.54 \pm 3.39^{\mathrm{i}-\mathrm{m}}$ & $30.48 \pm 3.13^{\mathrm{c}-\mathrm{i}}$ & $38.80 \pm 2.42^{\mathrm{a}}$ & $14.30 \pm 1.82^{\mathrm{a}-\mathrm{f}}$ & $10.99 \pm 0.90^{\mathrm{a}-\mathrm{d}}$ \\
\hline $\mathrm{S} 3 \cdot \mathrm{U}$ & $98.08 \pm 4.84^{\mathrm{e}-\mathrm{i}}$ & $54.56 \pm 5.19^{\mathrm{ab}}$ & $33.06 \pm 2.66^{\mathrm{ab}}$ & $22.12 \pm 3.02^{\mathrm{a}}$ & $16.14 \pm 1.64^{\mathrm{a}}$ \\
\hline
\end{tabular}

Means sharing the same letters in a row or in a column are statistically non-significant $(P>0.05)$. Small letters represent comparison among interaction means and capital letters are used for overall mean. S1-3; polluted Experimental sites in the River, Fish Types (F; farmed, P; polluted, U; up-steam, +ve; positive control).

omega series were reported in the flesh of fish from the habitat of high intensity pollution, less than half of that reported from the healthy farmed environment. The loss of these beneficial fatty acids could not be compensated for when a majority of the diet comprises of fish. The loss of essential unsaturated fatty acids due to the habitat effect could only be avoided by consuming fish from a healthy environment or improving the fish habitat.

\section{DISCUSSION}

The present study reveals the disturbance concerning the quality of the water of the River Chenab due to the presence of large amounts of heavy metals. All the heavy metals studied were found in higher amounts than the WHO permissible limits. The studies of Alink et al. (2007) and Obiakor et al. (2010) strongly corroborate the findings of the present study as the River Chenab is heavily polluted by the industry in the city of Faisalabad. A huge population depends on the water from the River Chenab as this body of water largely contributes to agriculture and fisheries. The toxins in the water revealed genotoxins which have the ability to induce irreversible DNA damage and chromosomal aberrations. The fish exposed to the polluted waste waters showed a large number of micronuclei and chromosomal aberrations when compared to the control fish as shown by comparison with the farmed fish and fish from upstream areas, thus confirming the findings of Flammarion et al. (2002).

The Cirrhinus mrigala showed the lowest consumer preference in the vicinity of the River Chenab even from less polluted areas of the river. In this study $97.40 \%$ of the people questioned had identified and rejected fish from the unhealthy habitat due to its gaze and aroma. The present findings showed 


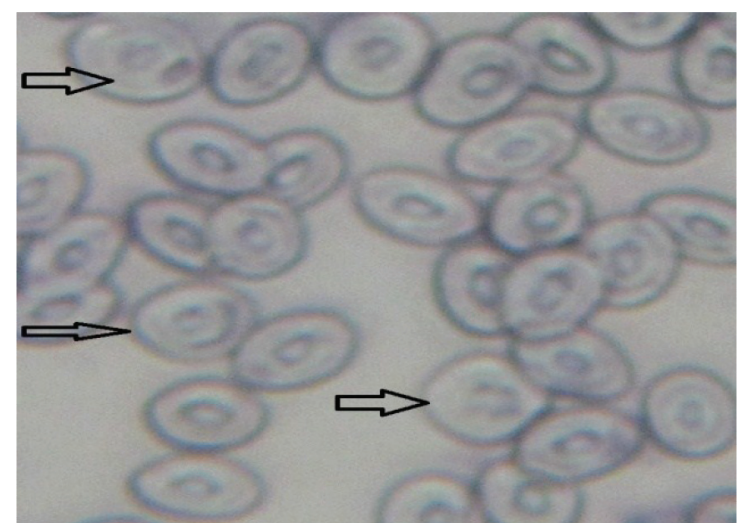

FIGURE 4. Micronucleus assay of fish (Cirrhinus mrigala) blood harvested from the polluted area of the River Chenab indicating nuclear abnormalities and micronucleus induction.

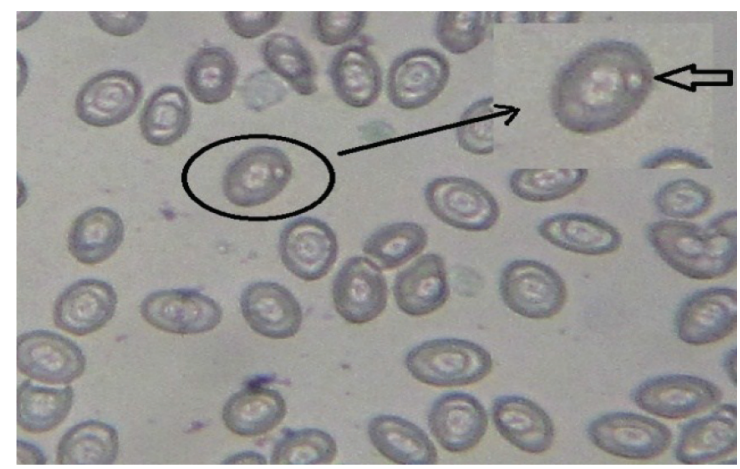

FIGURE 5. Micronucleus assay of fish (Cirrhinus mrigala) blood harvested from the polluted area of the River Chenab indicating micronucleus induction (P.Contrast).

a loss in polyunsaturated fatty acids along with significant DNA damage, which is in accordance with the findings of Hussain et al. (2011). Most of the current literature concerning the combined effects of heavy metals on fish mainly comes from histopathological and physiological studies while information about the potential genotoxic effects on this vertebrate group is still scarce (Galindo et al., 2010). None of the data is available in the literature for the comparison of these findings as related to DNA damage and fatty acid profile until now and hence could be used for future perspectives.

Cirrhinus mrigala showed a very limited population in the experimental area and is found to be near extinction as the habitat of the fish is not suitable for the growth of the fish. High fat contents in fish help in their buoyancy as the density of the fat is lower than that of water; but it deters the movement of the fish even in low levels of pollution. Having high saturates accompanied with contaminants in the body requires more energy for the fish to perform daily activities especially during locomotion in struggle for food (Kandemir and Polat, 2007).

This project corroborates the study of Van-DerOost et al. (2003) for the use of fish biomarkers as indices for the effect of pollution. The present study showed an increased level of genotoxic damage when compared to farmed fish. The comet assay findings of Cirrhinus mrigala are in concordance with the results of Pavlica et al. (2011) in the context of environmental biomonitoring of genotoxicity in fish. The present findings are also in line with the findings of Burger and Gochfeld (2005) who also reported that higher concentrations of heavy metals in the water not only bioaccumulate in the fish body but also get in the way of metabolism, hence reducing the quality of the fish. Pietripiana et al. (2002) also reported elevated levels of micronuclei frequencies in erythrocytes of fish collected from an unhealthy habitat which is in agreement with the study's' findings but no one has related these findings to the fatty acid profile of fish. Perhaps this is among the major factors leading to the extinction of this fish species in the polluted areas of the River Chenab. The fish from unpolluted areas clearly indicated higher levels of omega-3 polyunsaturated fatty acids and reasonable concentrations of saturated fatty acids.

Here it is important to point out the Cirrhinus mrigala's sensitivity to pollution after showing no significant differences in the amount of saturated and unsaturated fatty acids from both categories of experimental polluted and upstream fish specimens,

TABLE 2. DNA damage by Micronucleus assay of Cirrhinus mrigala blood.

\begin{tabular}{lccc}
\hline & \multicolumn{3}{c}{ Micronucleus assay components } \\
\cline { 2 - 4 } Fish Type & Single Micronucleus & Double Micronucleus & Nuclear Abnormalities \\
\hline Polluted & $44.80 \pm 3.73^{\mathrm{a}}$ & $06.20 \pm 0.97^{\mathrm{ab}}$ & $09.60 \pm 1.72^{\mathrm{a}-\mathrm{d}}$ \\
Upstream & $20.60 \pm 4.02^{\mathrm{bcd}}$ & $05.20 \pm 1.53^{\mathrm{b}}$ & $10.00 \pm 1.05^{\mathrm{a}-\mathrm{d}}$ \\
Control (Farmed) & $08.20 \pm 2.20^{\mathrm{cd}}$ & $00.80 \pm 0.37^{\mathrm{b}}$ & $06.20 \pm 1.85^{\mathrm{bcd}}$ \\
+ve. Control & $37.40 \pm 3.92^{\mathrm{ab}}$ & $08.40 \pm 2.80^{\mathrm{ab}}$ & $15.20 \pm 2.06^{\mathrm{ab}}$ \\
Mean & $27.75 \pm 3.66^{\mathrm{A}}$ & $05.15 \pm 1.00^{\mathrm{AB}}$ & $10.25 \pm 1.08^{\mathrm{A}}$
\end{tabular}

Means sharing the same letters in a row or in a column are statistically non-significant $(P>0.05)$. Small letters represent comparison among interaction means and capital letters are used for overall mean. Frequency calculated per thousand cells. 
Habitat induced mutational effects and fatty acid profile changes in bottom dweller Cirrhinus mrigala inhabitant of river chenab $\bullet$

TABLE 3. Fatty acid profile of Cirrhinus mrigala meat harvested from three different habitats

\begin{tabular}{|c|c|c|c|}
\hline Fatty acids & Wild Polluted area fish & Wild Non-polluted area fish (upstream) & Farmed Fish \\
\hline \multicolumn{4}{|c|}{ Saturated fatty acids } \\
\hline $\mathrm{C} 8: 0$ & - & - & - \\
\hline C10:0 & $07.7949 \pm 0.88^{\mathrm{b}}$ & $01.3262 \pm 0.04^{\mathrm{ad}}$ & $03.4125 \pm 0.05^{\mathrm{ac}-\mathrm{f}}$ \\
\hline $\mathrm{C} 12: 0$ & - & $00.6923 \pm 0.05^{\text {abe }}$ & $01.0547 \pm 0.03^{\mathrm{abc}}$ \\
\hline C14:0 & $02.4699 \pm 0.05^{\mathrm{abd}}$ & $00.4762 \pm 0.01^{\mathrm{b}}$ & $04.2143 \pm 0.09^{\mathrm{b}}$ \\
\hline $\mathrm{C} 16: 0$ & $54.9414 \pm 2.14^{\mathrm{def}}$ & $41.9244 \pm 1.09^{\mathrm{ab}}$ & $12.0025 \pm 0.23^{\text {abe }}$ \\
\hline $\mathrm{C} 18: 0$ & $10.1358 \pm 0.15^{\mathrm{gh}}$ & $28.4393 \pm 2.04^{\text {cde }}$ & $07.0658 \pm 0.10^{\mathrm{ab}}$ \\
\hline $\mathrm{C} 20: 0$ & - & $01.1707 \pm 0.02^{\mathrm{ah}}$ & $00.2540 \pm 0.10^{\mathrm{abd}}$ \\
\hline$\Sigma$ SFA & $75.3370 \pm 0.80^{\text {abef }}$ & $74.0291 \pm 0.54^{\mathrm{ab}}$ & $28.0038 \pm 0.07^{\mathrm{ab}}$ \\
\hline \multicolumn{4}{|c|}{ Monounsaturated fatty acids } \\
\hline $\mathrm{C} 16: 1(\mathrm{n}-7)$ & - & - & $00.5073 \pm 0.02^{\mathrm{bc}}$ \\
\hline C16:1(n-9) & - & $00.3900 \pm 0.01^{\mathrm{abh}}$ & $02.5471 \pm 0.01^{\mathrm{ac}}$ \\
\hline C18:1(n-7) & $00.4688 \pm 0.08^{\mathrm{af}}$ & $00.3472 \pm 0.03^{\text {bef }}$ & $01.4587 \pm 0.02^{\mathrm{acd}}$ \\
\hline C18:1(n-9) & - & $00.0742 \pm 0.12^{\mathrm{ab}}$ & $11.8905 \pm 0.07^{\text {abe }}$ \\
\hline C20:1(n-9) & - & - & $03.5412 \pm 0.19^{\mathrm{ab}-\mathrm{d}}$ \\
\hline C22:1(n-9) & $05.2212 \pm 0.10^{\mathrm{bc}}$ & $00.3526 \pm 0.10^{\mathrm{ab}}$ & $00.6039 \pm 0.03^{\mathrm{ab}}$ \\
\hline$\Sigma$ MUFA & $05.6900 \pm 0.09^{\mathrm{c}-\mathrm{f}}$ & $01.1640 \pm 0.06^{\mathrm{abc}}$ & $20.5481 \pm 0.05^{\mathrm{ab}}$ \\
\hline \multicolumn{4}{|c|}{ Polyunsaturated fatty acids } \\
\hline C18:2(n-6) & - & $01.1625 \pm 0.09^{\text {abe }}$ & $00.0122 \pm 0.02^{\mathrm{abe}}$ \\
\hline C18:3(n-3) & $02.4446 \pm 0.12^{\mathrm{bc}}$ & $04.0059 \pm 0.02^{\mathrm{abf}}$ & $06.2521 \pm 0.12^{\mathrm{ac}}$ \\
\hline C18:4(n-3) & - & $00.3921 \pm 0.07^{\text {ade }}$ & $00.5543 \pm 0.01^{\mathrm{abc}}$ \\
\hline$C 20: 2(n-6)$ & $00.9421 \pm 0.09^{\mathrm{bdf}}$ & - & $00.6302 \pm 0.01^{\mathrm{abc}}$ \\
\hline C20:4(n-6) & $08.2893 \pm 0.03^{\text {adef }}$ & $00.4425 \pm 0.04^{\text {abe }}$ & $10.6500 \pm 0.62^{\text {ace }}$ \\
\hline$C 20: 5(n-6)$ & $03.0386 \pm 0.10^{\text {ah }}$ & $07.6222 \pm 0.09^{\text {afe }}$ & $00.1140 \pm 0.12^{\text {abe }}$ \\
\hline $\mathrm{C} 20: 5(\mathrm{n}-3)$ & - & $00.1199 \pm 0.13^{\text {abe }}$ & $07.8503 \pm 0.42^{\mathrm{b}-\mathrm{h}}$ \\
\hline$C 22: 4(n-6)$ & - & - & $00.4441 \pm 0.01^{\text {ace }}$ \\
\hline$C 22: 5(n-6)$ & $00.1366 \pm 0.03^{\mathrm{abg}}$ & $04.9590 \pm 0.06^{\text {ace }}$ & $06.0210 \pm 0.06^{\mathrm{cdf}}$ \\
\hline $\mathrm{C} 22: 5(\mathrm{n}-3)$ & $03.3439 \pm 0.04^{\mathrm{acd}}$ & - & $02.0129 \pm 0.02^{\mathrm{abc}}$ \\
\hline C22:6(n-3) & $00.1151 \pm 0.02^{\mathrm{abc}}$ & $02.2750 \pm 0.03^{\text {ade }}$ & $07.0014 \pm 0.14^{\mathrm{ab}}$ \\
\hline$\Sigma$ PUFA & $18.3102 \pm 0.06^{\mathrm{ab}}$ & $20.9791 \pm 0.07^{\text {abe }}$ & $49.5425 \pm 0.14^{\text {abe }}$ \\
\hline
\end{tabular}

Data are Mean \pm SE expressed as a percentage of total FA methyl esters analyzed in triplicate. Different letters in superscript in the same row represent significant $(P<0.05)$ difference. $\Sigma$ SFA; Saturated fatty acids, $\Sigma$ MUFA; Monounsaturated fatty acids, $\Sigma$ MUFA; Polyunsaturated fatty acids.

which indicates a higher sensitivity to pollution; whereas the normal distribution of the fatty acid profile was reported in farmed specimens. This is due to the pollution sediment with the passing of time (Koca et al., 2008) in the bottom of the river and the fact that the Cirrhinus mrigala is a bottom feeder fish and receives maximum exposure to the pollution.

\section{CONCLUSION}

Unhealthy habitats not only escort toxicant bioaccumulation in the fish body but also induce DNA damage leading to the loss of essential fatty acids particularly of the omega series. Peoples consuming fish for its omega series of unsaturated fatty acids must ensure where the fish were harvested from as it may be deficient in these fatty acids. There is a dire need to pay further attention to this freshwater body to monitor freshwater pollution and its genotoxic potential for the current scenario.

\section{ACKNOWLEDGMENTS}

The authors would like to express their sincere appreciation to the Deanship of Scientific Research at King Saud University for its funding of this research through the Research Group Project No. RG-1435-012. 


\section{REFERENCES}

Ackman RG. 1967. Characteristics of the fatty acid composition and biochemistry of some freshwater fish oils and lipids in comparison with marine oils and lipids. Camp. Biochem. Physiol. 22, 907-922. http://dx.doi.org/ 10.1016/0010-406X(67)90781-5.

Alink GM, Quik JTK, Penders EJM, Spenkelink A, Rotteveel SGP, Maasc JL, Hoogenboezemb W. 2007. Genotoxic Effects in the Eastern Mud minnow (Umbra pygmaea L.) after Exposure to Rhine water, as Assessed by Use of the SCE and Comet Assays: A Comparison between 1978 and 2005. Mutat. Res. 631, 93-100. http://dx.doi.org/10.1016/j. mrgentox.2007.03.011.

APHA. 1998. Standard Methods for the Examination of Water and Waste water. 20th Ed. American Public. New York, USA.

Baršienė J, Rybakovas A, Lang T, Andreikènaitė L. Michailovas A. 2013. Environmental genotoxicity and cytotoxicity levels in fish from the North Sea offshore region and Atlantic coastal waters. Mar. Pollut. Bull. 68, 106-16. http://dx.doi. org/10.1016/j.marpolbul.2012.12.011.

Bell JG, McVicar AH, Park MT, Sargent RJ. 1991. Effect of high dietary linolecic acid on fatty acid compositions of individual phospholipids from tissues of Atlantic salmon (Salmo salar): Association with a novel cardiac lesion. $J$. Nutr. 121, 1163-1172.

Boyd EC.1981. Water quality in warm water fish ponds. $2^{\text {nd }} \mathrm{Ed}$. Craftmaster Printers Inc Opelika Albama. pp 213-247.

Burger J, Gochfeld M. 2005. Heavy metals in commercial fish in New Jersey. Environ Res. 99, 403-12. http://dx.doi.org/ 10.1016/j.envres.2005.02.001.

Burr ML, Fehily AM, Gilbert JE. 1989. Effect of changes in fat, fish and fiber intakes on death and myocardial reinfarction; diet and reinfarction trial (DART). Lancet. 2, 757-761. http://dx.doi.org/10.1016/S0140-6736(89)90828-3

Dhawan A, Bajpayee M, Pandey AK, Parmar D. 2009. Protocol for the single cell gel electrophoresis/comet assay for rapid genotoxicity assessment. Developmental Toxicology Division Industrial Toxicology Research Centre Marg, Lucknow226001U.P. [Internet]. Available from http//www. cometassayi ndia.org/Protocol $\% 20$ for $\% 20$ Comet $\% 20$ Assay. PDF/ Assessed Sep. 21, 2013.

El-Bouraie MM, El-Barbary AA, Yehia MM, Motawea EA. 2010. Heavy metal concentrations in surface river water and bed sediments at Nile Delta in Egypt. Suo. 61, 1-12.

Folch J, Lees M, Stanely SGH. 1957. A simple method for the isolation and purification of total lipids from animal tissues. J. Biol. Chem. 226, 497-509.

Galindo BA, Troilo G, Cólus IMS, Martinez CBR, Sofia SH. 2010. Genotoxic Effects of Aluminum on the Neotropical Fish Prochilodus lineatus. Water Air Soil Pollut. 212, 419-428. http://dx.doi.org/10.1007/s11270-010-0357-5.

Goher MA. 1998. Factors affecting the precipitation and dissolution of some chemical elements in River Nile at Damietta branch. M.Sc. Thesis fact of Sci Menofia Univ Egypt.

Hussain B, Mahboob S, Hassan M, Nadeem S, Sultana T. 2011. Effect of maturation degree on fatty acid profile of different tissues in wild and farmed rohu (Labeo rohita).
Grasas Aceites, 62, 206-212. http://dx.doi.org/10.3989/ gya.090510.

Kandemir S, Polat N. 2007. Seasonal Variation of total lipids and total fatty acids in muscle and liver of Rainbow Trout (Oncorhynchus mykiss) reared in Derbent Dam Lakeb. TrJFAS 7, 27-31.

Kiessling A, Pickova J, Johansson L, Asgard T, Storebakken T, Kiessling KH. 2001. Changes in fatty acid composition in muscle and adipose tissue of farmed rainbow trout (Oncorhynchus mykiss) in relation to ration and age. Food Chem. 73: 271-284. http://dx.doi.org/10.1016/S0308-8146 (00)00297-1.

Koca S, Koca YB, Yildiz S, Gürcü B. 2008. Genotoxic and Histopathological Effects of Water Pollution on Two Fish Species, Barbus capito pectoralis and Chondrostoma nasus in the Büyük Menderes River, Turk. Bio. Tra Elem. Res. 122, 276-291. http://dx.doi.org/10.1007/s12011-007-8078-3.

Nhapi I, Wali UG, Uwonkunda BK, Nsengimana H, Banadda N, Kimwaga BK. 2011. Assessment of water pollution levels in the Nyabugogo Catchment, Rwanda. TOENVIEJ. 4, 40-53. http://dx.doi.org/10.2174/1874829501104010040.

Obiakor MO, Ezeonyejiaku CD, Ezenwelu CO, Ugochukwu GC. (2010). Aquatic genetic biomarkers of exposure and effect in Catfish (Clarias gariepinus, Burchell, 1822) Amer-Eur. J. Toxicol. Sci. 2, 196-202.

Pavlica M, Stambuk A, Malović L, Mladinić M, Göran I, Klobŭ VC. 2011. DNA integrity of chub erythrocytes (Squalius cephalus $L$.) as an indicator of pollution-related genotoxicity in the River Sava. Environ. Monit. Assess. 77, 85-94. http://dx.doi.org/10.1007/s10661-010-1620-3.

Pietripiana D, Modena M, Guidetti P, Falugi C, Vacchi M. 2002. Evaluating the genotoxic damage and hepatic tissue alterations in demersal fish species: a case study in the Liguarian Sea (N.W.Mediterranean). Mar. Pollut. Bull. 44, 238-343. http://dx.doi.org/10.1016/S0025-326X(01)00249-1.

Polvi SM, Ackman RG. 1992. Atlantic salmon (Salmo Salar) muscle lipids and their response to alternative dietary fatty acid sources. J. Agric. Food Chem. 40, 1001-1007. http:// dx.doi.org/10.1021/jf00018a018.

Shahidi F, Boota J. 1994. Seafood: chemistry, processing technology and quality, Chapman and Hall, London. pp 3-9. http://dx.doi.org/10.1007/978-1-4615-2181-5.

Singh NP, McCoy MT, Tice RR, Schneider EL. 1988. A simple technique for quantification of low levels of DNA damage in individual cells. Exp. Cell. Res. 175, 184-191. http:// dx.doi.org/10.1016/0014-4827(88)90265-0.

Tawfiq MEF. 1998. Seasonal distribution of cadmium in Lake Nasser, Aswan reservoir and River Nile at Aswan. Monoufia J. Agri. Res. 32, 391-414.

Van-Der-Oost R, Beyer J, Vermeulen NPE. 2003. Fish bioaccumulation and biomarkers in environmental risk assessment: a review. Environ. Toxicol. Phar. 13, 57-149. http://dx.doi. org/10.1016/S1382-6689(02)00126-6.

Villela IV, Oliveira IM, Silva J, Henriques JAP. 2006. DNA damage and repair in haemolynph cells of golden mussel (Limnoperna fortunei) exposed to environmental contaminants. Mutat. Res. 605, 78-86. http://dx.doi.org/10.1016/j. mrgentox.2006.02.006. 